\title{
Women's Medicine, Women's Culture: Abortion and Fortune-Telling in early Twentieth-Century Germany and the Netherlands
}

\author{
WILLEM DE BLÉCOURT and CORNELIE USBORNE*
}

If the history of medicine is approached from a cultural point of view, the range of meanings attached to both health and illness by ordinary people in everyday life emerges as far wider than the canon of academic medicine would have us believe. Health, for example, can be perceived as encompassing, well-being and good fortune; the experience of illness ranges from sickness, disease and distress to misfortune. Health is thus both a physical and an emotional, an individual as well as a social phenomenon. The direction of research undertaken by a medical historian should ideally be determined by the people who are being studied even if their views clash with the criteria prescribed by the medical profession. Thus indigenous perceptions, or those reconstructed by the historian, guide and inform cultural approaches to the history of medicine. ${ }^{1}$ Moreover, studying health and illness in the past entails looking at processes of healing, which can range from talking about, diagnosing or preventing an illness to caring for or curing a sufferer.

In the following we adopt this approach "from below" since we share the belief of medical and social anthropologists that body and mind are not historically constant, ${ }^{2}$ and that illness has always been not only a biological but also a cultural event. Somatic and mental processes were always mediated by body images, vocabulary and explanatory models. Similarly, we believe in the social construction of health and illness; that the perception of being well or unwell depended on the specific historical situation, and as such it was often contested. Thus we should expect differences of opinion between sufferer on the one hand and carer or healer on the other which were related to class or ethnic divisions. Tensions also arose between various healers because of professional rivalries. Last, but not least, there was the possibility of opposing views between men and women rooted in gender differences. Indeed, in recent western European society the experience of health and illness and the pursuit of healing were likely to have been genderspecific. This could hardly have been otherwise in a patriarchal society which was shaped

* Willem de Blécourt, PhD, Huizinga Instituut, Spuistraat 134, 1012 VB Amsterdam, The Netherlands. Cornelie Usborne, $\mathrm{PhD}$, History Department, Roehampton Institute, Digby Stuart College, Roehampton Lane, London SW15.5PH, UK.

1 Cf. Byron J Good, Medicine, rationality, and experience: an anthropological perspective,

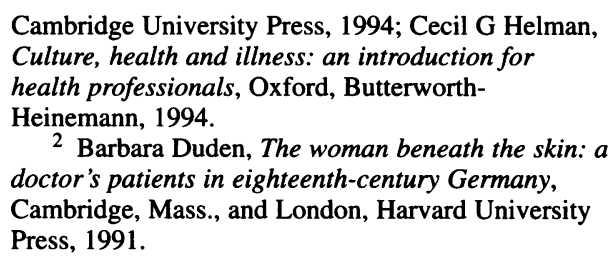

Cambridge University Press, 1994; Cecil G Helman, Culture, health and illness: an introduction for health professionals, Oxford, ButterworthHeinemann, 1994.

2 Barbara Duden, The woman beneath the skin: a doctor's patients in eighteenth-century Germany, Cambridge, Mass., and London, Harvard University Press, 1991. 
by an unequal power relationship between women and men and in which the two sexes had been allocated their own specific spheres. As much feminist research has argued, the latter was a direct result of the separation during the nineteenth century between public and private life, rationality and emotion, work and home, which influenced the experiences of and attitude towards women, particularly middle-class women. ${ }^{3}$ But women of all classes were affected by the dominant belief in a "natural" gender polarity which was postulated in tracts, scholarly writings and encyclopaedias. These viewed male and female characteristics as complementary yet also hierarchical. Thus gender inequality was understood as a product of the natural order. The role of science and medicine was crucial in proclaiming this new and profound sense of an all-embracing difference between the sexes. ${ }^{4}$

The notion of gendered health and healing has been espoused particularly by sociologists addressing our experiences today. They have argued on several occasions that men and women in western society use different definitions of illness ${ }^{5}$ since these are intimately linked to notions of masculinity and femininity. The anthropologist Emily Martin, for instance, investigated women's views of reproduction and found that "the concrete incidents of women's everyday lives can evoke glimpses of other ways of living, other ways of using time, other ways of conveying the sense of menstruation, birth, and menopause". 6 Recent research has also shown that strategies pursued to get well are gendered. ${ }^{7}$ How much the belief in a "natural" gender polarity survives today is revealed in a recent sociological survey which showed "that both men and women believed women coped better with pain because it was a fact of nature". 8 Yet social historians of medicine have seldom concerned themselves with the gendered conceptions of illness and healing.

\footnotetext{
3 We are aware of the criticism recently voiced by feminist historians on the crude separate sphere model and we grant that the boundaries between public/private, female/male sphere have in reality been blurred and contested; nevertheless we believe this dichotomy reflected an important aspect of patriarchal society, a kind of "western folk model". Cf. Henrietta L Moore, "The difference within and the difference between', in Teresa del Valle (ed.), Gendered anthropology, London and New York, Routledge, 1993, pp. 193-204. See also, Lynn Abrams and Elizabeth Harvey (eds), Gender relations in German history: power, agency and experience from the sixteenth to the twentieth century, London, UCL Press, 1996, especially the introduction; Belinda Davis, 'Reconsidering Habermas, gender and the public sphere: the case of Wilhelmine Germany', in Geoff Eley (ed.), Society, culture, and the state in Germany, 1870-1930, Ann Arbor, The University of Michigan Press, 1997, pp. 397-426. As to empirical evidence of separate spheres, from the vast Anglo-Saxon literature on the subject, see, for example, Leonore Davidoff and Catherine Hall, Family fortunes: men and women of the English middle class, 1780-1850, London, Hutchinson, 1987; for Germany, Ute Frevert, Bürgerinnen und Bürger: Geschlechterverhältnisse im 19. Jahrhundert, Göttingen, Vandenhoeck \&
}

Ruprecht, 1988, and Karin Hausen, 'Family and roledivision: the polarization of sexual stereotypes in the nineteenth century - an aspect of the dissociation of work and family life', in R J Evans and W R Lee (eds), The German family, London, Croom Helm, 1981, pp. 51-83.

${ }^{4}$ Cf. Ludmilla Jordanova, Sexual visions: images of gender in science and medicine between the eighteenth and twentieth centuries, New York, Harvester Wheatsheaf, 1989; Ornella Moscucci, The science of woman: gynaecology and gender in England, 1800-1929, Cambridge University Press, 1990.

5 In this instance we are not concerned with biological differences. Cf. Beate A. Schücking 'Weiße Flecken in der Landschaft: Frauenforschung in der Medizin', in Elisabeth Mixa, et al. (eds), in Körper-Geschlecht-Geschichte. Historische und aktuelle Debatten in der Medizin, Innsbruck and Vienna, Studien Verlag, 1996, pp. 229-43.

6 Emily Martin, The woman in the body: a cultural analysis of reproduction, Boston, Beacon Press, 1987, pp. 201-2.

${ }^{7}$ For example, Margaret Stacey, The sociology of health and healing: a textbook, London and New York, Routledge, 1991, pp. 145-9.

8 The Times Higher Educational Supplement, 10 April 1998, p. 7. 


\section{Willem de Blécourt and Cornelie Usborne}

This is no doubt partly due to the continuing dominance of a male medical and scientific discourse which marginalized women's views and contributions, and partly because the types of health care services in which women dominated were to a large extent informal and thus invisible, and also frequently contravened orthodox theories and therefore escaped official records. If we as historians wish to make them visible we need a different methodology, we need to ask different questions which will lead us to new source material.

This entails taking seriously informal health care of the sick and troubled ${ }^{9}$ as well as recognising the role of preventive and palliative care of such mundane everyday routines like the housewife's efforts to keep the house clean and warm and to feed and care for the family in illness and in health. ${ }^{10}$ But it also means shedding more light on women's unorthodox advice and treatment in the marketplace. The importance of women practitioners of non-regular or lay medicine for what we would argue constituted a particular female culture of health and healing was by no means only a feature of preindustrial European society but continued, as we hope to show below, well into the twentieth century. Nor was it confined to the countryside. On the contrary, the specific practices which we have researched were much more an urban than a rural phenomenon and they thrived especially in the big cities. A new recognition of the diverse and wideranging role of female health care providers (where health is taken in the broad sense mentioned above) must also lead to a re-evaluation of women's activity in the public domain.

Ideally any enquiry into gendered attitudes to medicine would give equal weight to female and male views and practices, and would explore the interrelationship between them. Clearly this is beyond the scope of an article like this. We can only hope to open up the debate by looking at the very areas which have received least attention: genderspecific attitudes and actions by many ordinary women during the last hundred years or so in two European countries. If we concentrate here only on women, it does not, of course, mean that the concerns of men have been omitted. Male ideas remain present, not only in the dominant medical discourse but in society at large, which was after all organized according to an unequal sexual system. Male concerns also pervaded most source material for the study of female culture since rare glimpses into the "private" world of women's everyday life are often only afforded the historian when contemporary male figures of authority like policemen, lawyers or journalists had scrutinized female behaviour in the first place. Specifically female forms of health care were, moreover, not necessarily used to the exclusion of more conventional methods like consulting a doctor. Moreover, as we will see, men were also an important component of female care, as husbands, boyfriends, fathers or sons were the objects of care or the source of problems to begin with and thus the relationship between the two sexes is at the very heart of this examination.

9 For example, Regina Markell Morantz, 'Nineteenth century health reform and women: a program of self-help', in Günter B Risse, Ronald L Numbers and Judith Walzer Leavitt (eds), Medicine without doctors: home health care in American history, New York, Science History Publications, 1977, pp. 73-93.
10 Hilary Graham, 'Providers, negotiators, and mediators: women as the hidden carers', in Ellen Lewin and Virginia Olesen (eds), Women, health, and healing: towards a new perspective, New York and London, Tavistock, 1985, pp. 25-52. 


\section{Women's Medicine, Women's Culture}

In this paper we will examine the relationship between lay or irregular healing and women in respect of both female practitioners and female patients. We will do so by highlighting two specific areas which have so far attracted relatively little attention in the social history of medicine of the modern era, namely the experience of abortion and fortune-telling, particularly for women of the lower classes for whom they were often an everyday event. ${ }^{11}$

\section{Historiography, Sources and Questions}

In the social history of medicine, especially as it is practised in Germany and the AngloSaxon countries, there is no substantial body of literature covering our subject during the post-1850 period in Europe. Women, either as lay practitioners or as patients using lay medicine, have been doubly neglected "by their gender and their medical affiliation". 12 Whenever historians have studied fringe medicine or quackery on its own or as part of a general medical study, they have mainly restricted their attention to the pre-1850 period. $^{13}$ Studies of folk medicine which do cover more recent years have for the most part concentrated on a selective sample of remedies rather than on the healers prescribing or the patients using them. ${ }^{14}$ The same is true of those few historians of "alternative medicine" who have ventured into the modern period; they have focused on therapeutic methods and organizations, on the legal position and campaigns to change it. Cornelia Regin's study of the nature therapy movement in Imperial Germany is such an example. ${ }^{15}$ As a pioneering study of a neglected field it should be applauded. Yet by concentrating on organizations and notwithstanding a careful analysis of the naturopaths' magazines, the "view from below" and an analysis according to gender are largely neglected. Robert Jütte's recent popular book on the history of alternative medicine since the early nineteenth century in Germany throws light on a vast array of unorthodox practices and the often bitter feuds between their supporters and the camp of academic medicine. Sufferers' deliberations are much less well covered and sex-specific aspects all but

11 Cf. Willem de Blécourt, 'Kaartlegsters, helderzienden en afdrijfsters. Stedelijke genezeressen in het begin van de twintigste eeuw', in Rineke van Daalen and Marijke Gijswijt-Hofstra (eds), Gezond en Wel. Vrouwen en de zorg voor gezondheid in de twintigste eeuw, Amsterdam University Press, 1998, pp. 175-88, 278-80, which concerns both fortunetelling and abortion.

12 Naomi Rogers, 'Women and sectarian medicine', in Rima D Apple (ed.), Women, health and medicine in America: a historical handbook, New Brunswick, Rutgers University Press, 1992, pp. 273-302, p. 274.

13 See, for example, Matthew Ramsey, Professional and popular medicine in France, 1770-1830: the social world of medical practice, Cambridge and New York, Cambridge University Press, 1988; Mary Lindemann, Health and healing in eighteenth-century Germany, Baltimore and London, Johns Hopkins University Press, 1996.

${ }^{14}$ Cf. Françoise Loux, 'Folk medicine', in W F
Bynum and Roy Porter (eds), Companion encyclopedia of the history of medicine, London and New York, Routledge, 1993, pp. 661-75; Elfriede Grabner, 'Volksmedizin', in Rolf W Brednich (ed.), Grundriss der Volkskunde. Einfuihrung in die Forschungsfelder der europäischen Ethnologie, Berlin, Reimer, 1988, pp. 423-46. David J Hufford, 'Folk medicine in contemporary America', in James Kirkland, et al. (eds), Herbal and magical medicine: traditional healing today, Durham and London, Duke University Press, 1992, pp. 14-31.

15 Cornelia Regin, Selbsthilfe und

Gesundheitspolitik. Die Naturheilbewegung im Kaiserreich (1889 bis 1914), Stuttgart, Franz Steiner, 1995. Cf. Martin Dinges, 'Medizinkritische Bewegungen zwischen "Lebenswelt" und "Wissenschaft", in Martin Dinges (ed.), Medizinkritische Bewegungen im Deutschen Reich (ca. 1870-ca. 1933), Stuttgart, Franz Steiner, 1996, p. 29. 
missing. ${ }^{16}$ There are some studies of individual unorthodox practitioners, it is true, but these also ignore gender and usually describe exclusively the practice of men. ${ }^{17}$ Even feminist historians exploring the role of gender in European medicine have for the most part concentrated on elite medicine, examining the special place of women doctors, the discrimination they faced and their pioneering role in opening up the profession. ${ }^{18}$ In studies of women physicians in the United States, however, historians like Regina Morantz-Sanchez have found that many women doctors were in fact sectarians, constituting a larger proportion than their male colleagues in this field, and that a number of women even switched from practising orthodox to homoeopathic medicine. ${ }^{19}$ Indeed, the earliest formal education of American women practitioners took place in irregular, sectarian colleges which taught medicine through more or less organized medical systems, like homoeopathy, hydropathy, magnetism or nature therapy. This brought sectarian medicine to the attention of historians. Jane Donegan and Susan Cayliff have traced the careers of women hydropaths. ${ }^{20}$ Cursory examination of sectarian biographical texts suggests that women practitioners were a significant part of irregular medicine in America. But it is questionable whether the development of sectarian medical colleges in the United States throws much light on the European situation. Whatever the geographical definition, scarce attention has been given to female practitioners without any formal medical training and their female clients.

Of course, the source material is difficult to trace, especially for the views of women sufferers even though there have been a number of ingenious attempts to find evidence. Recently, Marita Metz-Becker has used infanticide cases as well as records of early nineteenth-century lying-in hospitals to show the attitude of poor single women towards elite medicine. ${ }^{21}$ Barbara Elkeles and Gunnar Stollberg, for example, have consulted German workers' autobiographies. Together with Jens Lachmund, Stollberg has also investigated a multitude of bourgeois and aristocratic biographies including some by women from the nineteenth and twentieth centuries. ${ }^{22}$ But the question of a gendered

16 Robert Jütte, Geschichte der Alternativen Medizin: von der Volksmedizin zu den unkonventionellen Therapien von heute, Munich, $\mathrm{C}$ H Beck, 1996.

$17 \mathrm{Cf}$. the contribution of Robert Jütte in this issue.

${ }^{18}$ For example, Christa Lange-Mehnert, "'Ein Sprung ins absolute Dunkle”. Zum Selbstverständnis der ersten Ärztinnen: Marie Heim-Vögtlin und Franziska Tiburtius', in Johanna Geyer-Kordesch, Annette Kuhn (eds), Frauenkörper, Medizin, Sexualität, Düsseldorf, Schwann, 1986, pp. 286-310; Eva Brinkschulte (ed.), Weibliche Ärzte. Die Durchsetzung des Berufsbildes in Deutschland, Berlin, Edition Hentrich, 1995; Johanna GeyerKordesch, 'Women and Medicine', in Bynum and Porter (eds), op. cit., note 14 above, pp. 888-914; Kristin Hoesch, Ärztinnen für Frauen. Kliniken in Berlin 1877-1914, Stuttgart and Weimar, Metzler, 1995. See also the 1994 symposium held at the Wellcome Institute for the History of Medicine, London, on 'Women in modern medicine', organized by Anne Hardy and Larry Conrad.
19 Regina Markell Morantz-Sanchez, Sympathy and science: women physicians in American medicine, New York and Oxford, Oxford University Press, 1985.

20 Susan E Cayleff, Wash and be healed: the water-cure movement and women's health, Philadelphia, Temple University Press, 1987; idem, 'Gender, ideology, and the water-cure', in Norman Gevitz (ed.), Other healers: unorthodox medicine in America, Baltimore and London, Johns Hopkins University Press, 1988, pp. 82-98. Jane B Donegan, "Hydropathic Highway to Health": women and water-cure in antebellum America, New York and Westport, Greenwood Press, 1986.

21 Marita Metz-Becker, Der verwaltete Körper. Die Medikalisierung schwangerer Frauen in den Gebärhäusern des frühen 19. Jahrhunderts, Frankfurt and New York, Campus, 1997.

22 Gunnar Stollberg, 'Health and illness in German workers' autobiographies from the nineteenth and early twentieth centuries', in Soc. Hist. Med., 6: 261-76; Jens Lachmund, Gunnar Stollberg, Patientenwelten. Krankheit und Medizin 


\section{Women's Medicine, Women's Culture}

medical culture is here not explicitly addressed. Others have resorted to oral history, like Elisabeth Roberts for Lancashire and Kate Fisher for Cardiff, ${ }^{23}$ or evaluated judicial files to learn about the illegal practice of abortion by lay practitioners ${ }^{24}$ but without necessarily exploring the causal link between women's special needs and culture and their use of patent medicine and unorthodox practitioners. If they were studied at all, lay practitioners and their remedies were usually cast in an unfavourable light. The dominant contemporary view, largely constructed by the medical profession, that, for instance, "quack abortionists" were dangerous and irresponsible, has rarely been questioned critically by medical or feminist historians. ${ }^{25}$

Detailed historical studies also remain to be done to explain the appeal of the various forms of sectarian and unorthodox medicine, and to analyse the career options for women within them. It has been a commonplace in medical politics to underrate the appeal of lay medicine by describing it predominantly as a female "problem". A number of nineteenthand early twentieth-century medical men explained female enthusiasm for "patent medicines" and other "quackeries" by referring to prevailing gender norms: women were said to have a "natural" leaning towards the emotional and the superficial, and to suffer from an intrinsic hostility towards scientific explanations and methods. ${ }^{26}$ Without more systematic research, however, we do not know how widely these views were shared among the medical profession or whether it was indeed true that women preferred lay to orthodox medicine. In the absence of such research, we can only make informed guesses that women did not necessarily think in terms of a dichotomy between orthodoxy and "quackery", which was an artificial division even if it was an important concern of physicians engaged in the double process of professionalization and medicalization. Women who, as the chief providers of care within the household, looked after both sexes may well have availed themselves of one type of health care or another or both at the same time depending on different occasions or needs. But what these occasions or needs were remains to be discovered, as do the ways in which gender and other social categories like class and age influenced decisions to opt for one type of remedy rather than another.

By starting with the female sufferer's own definitions of illness and her strategy of how best to obtain the right cure we will try to offer a few tentative answers from our two case studies from Weimar Germany and early twentieth-century Netherlands. Although they

vom späten 18. bis zum frühen 20. Jahrhundert im Spiegel von Autobiographien, Opladen, Leske \& Budrich, 1995; see also Barbara Elkeles, 'Das Krankenhaus um die Wende vom 19. und 20. Jahrhundert aus der Sicht seiner Patienten', Historia Hospitalium, 1986-88, 17: 89-105.

${ }^{23}$ Elizabeth Roberts, 'Oral history investigations of disease and its management by the Lancashire working class 1890-1939', in J V Pickstone (ed.), Health, disease and medicine in Lancashire 1750-1950: four papers on sources, problems and methods, Manchester, UMIST, 1980, pp. 33-51; Kate Fisher, 'The culture of abortion in inter-war South Wales', in Franz Eder, Lesley Hall, and Gert Hekma (eds), Sexual culture in Europe: 2: Themes in sexuality, Manchester University Press, 1999.

24 For example, Barbara Brookes, Abortion in
England, 1900-1967, London, Croom Helm, 1988; Leslie J Reagan, When abortion was a crime: women, medicine, and law in the United States, 1867-1973, Berkeley and London, University of California Press, 1997.

25 For example, James Woycke, Birth control in Germany, 1871-1933, London and New York, Routledge, 1988, especially p. 75; cf. Cornelie Usborne, 'Abortion for sale! The competition between quacks and doctors in Weimar Germany', in Marijke Gijswijt-Hofstra, Hilary Marland and Hans de Waardt (eds), Illness and healing alternatives in western Europe, London and New York, Routledge, 1997, pp. 183-204, esp. 184-5.

26 For example, John Byers, 'Quackery-with special reference to female complaints', Br. med. J., 1911, i: $1239-42$. 


\section{Willem de Blécourt and Cornelie Usborne}

are contextually specific, the examples we furnish are meant to inspire further research into different practices and different places. Their value is first and foremost an illustration of approach and only secondly a description of particular practices. Our cases can perhaps best be evaluated within the context of the frequently expressed argument of availability in terms of costs and distance. The prevailing image, already in operation by the midnineteenth century, was that people resorted mainly to lay healers when there was no academically trained physician within easy reach or when a doctor was too expensive. But we found that geographical distance or financial considerations do not always seem to have been the decisive factor in women's choice for cures. This depended also on whether women had confidence that the doctor available would understand what ailed them and whether he would be prepared to help.

The most extreme form of rejection of academic medical concerns are cases of misfortune and illness which are ascribed to witchcraft. This was still surprisingly widely available as an explanation for physical and emotional problems in twentieth-century Europe. ${ }^{27}$ For example, Jeremy Seabrook wrote about a Northampton woman who had a simple-minded daughter: "Nothing would convince her that her girl's affliction was not the direct result of a neighbour's malevolence". ${ }^{28}$ People are known to have travelled long distances to consult a famous unwitching specialist rather than turn to a doctor nearby because medical men were thought ignorant of bewitchments. In witchcraft, as in other areas of illness and misfortune, it was usually mothers or wives, supported by a circle of acquaintances, who diagnosed the problem and chose the specialist to consult.

There is another illustration which counters the argument of medical availability. It is the Dutch concept of "healthy illness", which by definition did not need a doctor. A "healthy illness" was the colloquial expression for childbirth in a non-medicalized context. The term conveyed the ambiguity of lying-in which, although natural and therefore "healthy", also meant an incapacity of women to perform daily household chores. Delivering a baby was one of the few instances where the timely arrival of help really mattered, and birth attendance seems to have been one of the few areas where public policy was effective. ${ }^{29}$ Thus, in the course of the nineteenth and the early twentieth century, helpful female neighbours or the slightly more specialized handy-women were replaced by trained midwives and nurses. The exceptions to the rule may clarify the mechanisms of cultural (as opposed to material and geographical) availability, as there is evidence that some women still preferred unofficial help to the official midwife (more

\footnotetext{
27 For an overview, see Willem de Blécourt, 'The witch, her victim, the unwitcher and the researcher. The continued existence of traditional witchcraft', in Willem de Blécourt, Ronald Hutton and Jean la Fontaine, Witchcraft and magic in Europe: the twentieth-century, London, Athlone Press, 1999, pp. 141-219.

28 Quoted in Caroline Currer and Meg Stacey, Concepts of health, illness, and disease: $a$ comparative perspective, Leamington Spa and New York, Berg, 1986, p. 206.

${ }^{29}$ Cf. Hilary Marland, 'The medicalization of motherhood: doctors and infant welfare in the Netherlands, 1901-1930', in Valerie Fildes, Lara
}

\author{
Marks and Hilary Marland (eds), Women and \\ children first: international maternal and infant \\ welfare, 1870-1945, London and New York, \\ Routledge, 1992, pp. 74-96. More general: Ute \\ Frevert, 'The civilizing tendency of hygiene: \\ working-class women under medical control in \\ imperial Germany', in John C Fout (ed.), German \\ women in the nineteenth century: a social history, \\ New York, Holmes \& Meier, 1984, pp. 321-44; \\ idem, Krankheit als politisches Problem 1770-1880. \\ Soziale Unterschichten in Preußen zwischen \\ medizinischer Polizei und staatlicher \\ Sozialversicherung, Göttingen, Vandenhoeck \& \\ Ruprecht, 1984, pp.21, 28-36.
}




\title{
Women's Medicine, Women's Culture
}

rarely a doctor) even if the latter lived within walking (or cycling) distance. This was also true if, as was the case with the poor, the midwife's fees were paid by social welfare. We suggest that in these instances the trained midwife was culturally too far removed from the women giving birth. Mothers considered the official midwife's treatment as "too rough", implying that midwives had emulated male (medical) rather than female (trusted) behaviour. $^{30}$

\begin{abstract}
Abortion
Availability or otherwise of members of the medical profession who could and would help women rid themselves of unwanted pregnancies was not the main reason for the striking popularity of lay abortionists in Weimar Germany. According to newspaper reports and judicial files of criminal abortions many, probably most, women turned to a local network of information and support, often dominated by women, which would very frequently lead to a lay practitioner. ${ }^{31}$ Weise Frauen (wise women) and weise Männer (wise men), as they were called in working-class communities at the time, were indeed often the first port of call once an attempt at procuring a miscarriage either by the woman herself, or by a relative, neighbour or friend, had been unsuccessful. Reasons for this varied. Lay practitioners were considerably cheaper than their academically trained counterparts; costs obviously mattered since the majority of aborting women belonged to the lower social strata. As a rule, doctors charged high prices in order to make the risks they took worthwhile at a time when terminations were illegal. As in most other western European countries, the German Penal Code of 1871 had declared abortion a criminal offence punishable with imprisonment or even penal servitude. Therapeutic abortions, i.e. terminations on health grounds, were declared permissible only in 1927 when they could be carried out by doctors and paid for by the health insurance funds. These operations were, however, possible only on very narrowly defined grounds; they required a complicated and time-consuming procedure, which did not necessarily protect either the aborting woman or her abortionist from prosecution. ${ }^{32}$ In practice, women seeking a termination on other than strictly medical grounds were sent away by doctors but often told "to come back bleeding", 33 i.e. attempt an abortion elsewhere and then have the medical practitioner complete the necessary operation as an apparent emergency. The law notwithstanding, some doctors helped women out of humanitarian concern, and a fair number took a calculated risk of detection and potential imprisonment, as well as a loss of professional practice by running more or less lucrative abortion practices. ${ }^{34}$ In the mid- to

30 Willem de Blécourt, 'Dutch difference: prosecution of midwives in the late nineteenthcentury Netherlands', in Margaret L Arnot and Cornelie Usborne (eds), Gender and crime in modern Europe, London, UCL Press, 1999, pp. 189-203.

31 Cf. Cornelie Usborne, 'Wise women, wise men and abortion in the Weimar Republic: gender, class and medicine', in Lynn Abrams and Elizabeth Harvie (eds), Gender relations in German history, London, UCL Press, 1996, pp.143-76, 146-52.

32 According to a 1927 decree by the German Supreme Court a termination on health grounds was

permissible only in cases where a serious illness or potential death could not be averted by any other means and two doctors had to give their consent, see Cornelie Usborne, The politics of the body in Weimar Germany: women's reproductive rights and duties, London, Macmillan, 1992, pp.177, 214-15.

${ }^{33}$ Leo Klauber, 'Die Abtreibung', in Ludwig Levy-Lenz, Sexualkatastrophen. Bilder aus dem modernen Geschlechts- und Eheleben, Leipzig, A H Payne, 1926, p. 120.

34 Cf. Usborne, op. cit., note 32 above, p. 13; idem, op. cit., note 25 above, p. 191.
\end{abstract}




\section{Willem de Blécourt and Cornelie Usborne}

late 1920s doctors would charge even very poor women between 80 and 200 Reichsmarks. In contrast, their lay colleagues rarely asked for more than 30-50 RM, roughly the average weekly wage for a skilled woman textile worker. Sometimes their price was as little as 5 RM, little more than 2 pounds of butter. Frequently they agreed to a flexible financial arrangement, partly in money and partly in kind; they were not above accepting pledges such as wedding rings, bed and table linen or pieces of clothing. ${ }^{35}$ Especially during the hyperinflation in 1922 and 1923, transactions were often done entirely in kind and included a few pounds of flour, some sausages and meat or whatever the patient or her husband or boyfriend could offer, such as help with ploughing a field. ${ }^{36}$

There were, however, other less tangible reasons why women usually turned to lay abortionists, such as the status of the aborting woman vis-à-vis her abortionist. Women patients were relatively powerless when confronted with medical men. But with lay operators fee-paying women became clients and thereby gained a certain autonomy over their fate. Instead of appearing as supplicants before an academic expert who normally assumed the role of sole arbiter about abortion decisions and methods, wise women and men often allowed women at least some say in whether an operation would take place and also where and when, and how it would be paid for. Typically, many poor women negotiated lower rates and payment by instalments; some also withheld money if the intervention had not been successful. Sometimes, for example, women preferred to have the operation in their own homes when they could be assisted by their husbands, partners, friends or relatives.

Furthermore, the issue of class and gender shaped the relationship between the aborting woman and the abortionist in a crucial way. While lay abortionists were generally recruited from the lower classes and attracted predominantly women patients of their own social background, doctors were predominantly middle-class but were consulted by women of all classes. Thus, socio-economic and cultural affinity between practitioner and patient was an important reason for the popularity of wise women and wise men. Conversely, cultural and social differences between doctors-whether male or femaleand their patients made for a starkly hierarchical doctor-patient relationship. Whereas working-class women often shared the values and attitudes with lay practitioners and therefore also the same pragmatic view of abortion as a necessary strategy to avert disaster and restore social and emotional peace, many doctors occupied the moral high ground, making the aborting woman feel guilty of selfishness or even criminal behaviour. Wise women and wise men spoke the same language as their clients while doctors used academic or Latin terminology, which often intimidated patients without higher education or sometimes led to misunderstandings. Doctors described the operation in terms of their procedure and how the foetus would be extracted. They normally referred to Fruchtabtreibung (miscarriage of the foetus) by means of curettage, or of "laminaria sticks", a tamponage to be applied to the cervix. Women, on the other hand, usually thought only of how they themselves were affected by an unwanted pregnancy and how a termination would bring relief. In fact, in everyday German language any pregnancy, whether desired or not, could have a negative connotation: a pregnant woman was described as verfallen (failing, or having fallen) and a termination of this undesirable state

35 Landesarchiv Berlin, Rep. 58, Acc. 4005, no.

36 Usborne, op. cit., note 25 above, p. 192. 2439. 
would therefore by implication be seen in a positive light. Many working-class women never used the word abtreiben (abort) and instead described the act as kippen (tipping out), like getting rid of "waste". Similarly, in cases where pregnancy was not desired, the signs of menstruation were greeted with relief while a suspected pregnancy was often expressed in terms of "delayed monthly bleeding", a delay of the preferred state of infertility. Although the expression of "unblocking monthly blood" was often used in advertisements by commercial abortionists as an euphemism for illegal abortion, it also corresponded to women's experience and desire when their period had been delayed for whatever reason.

The question of gender often determined the preference for a lay abortionist, too. Generally, women preferred a female rather than a male abortionist and they approached operators who were not doctors. Women doctors do not seem to have been an option, possibly because their number was still limited and those who could have offered terminations were either reluctant or not in a position to do so; after all it could have meant jeopardizing a professional career which women had fought long and hard to gain access to in the first place. Amongst non-doctors performing abortions, in contrast, there was a high percentage of women, many of them midwives or former midwives who had been struck off the register because they had been convicted of illegal termination. As midwives they had sufficient gynaecological and general medical training to carry out the terminations carefully and conscientiously. The research suggests, however, that even non-midwives who had many years of abortion practice were usually a safe bet; they were also safer than most general practitioners who had neither learnt nor practised the process of induced miscarriage. There are indeed many instances when lay abortionists displayed a high degree of skill and conscientiousness, as was the case with the 53-year-old Martha S. from Berlin. Her mother had been a midwife near Magdeburg and her midwife manuals were the source for most of Frau S.'s anatomical knowledge. When her three children were grown-up and her husband had become a heavy drinker squandering his wages, Frau S. began to augment her housekeeping money by helping women with abortions. In 1927 she was reported to the police after she had quarrelled with a neighbour. She was eventually prosecuted and tried for abortion for commercial gain; after a lengthy trial she was convicted of abortion on at least twenty women (in reality this number was likely to have been much higher). Martha S. usually visited women in their own homes and administered an intrauterine douche of warm soap water with the aid of a syringe, which she had brought in her handbag. She had proceeded with sufficient care not to have harmed anybody, a fact attested by her patients when interviewed by the police. Apparently none of them had felt either pain during or any adverse effects after the operation. It also appeared that all her attempts to induce a miscarriage had succeeded. Interestingly, like a number of other women abortionists, she insisted on seeing her patients once they had miscarried. To be sure, this was partly to collect the final instalments of payment in cases when they had not been able to pay up front, but it was also to ensure that the miscarriage was complete and that the patient had not suffered. This kind of after-care appears to have happened rarely, if at all, whenever physicians ran commercial abortion practices.

There are many other examples of lay operators who behaved responsibly and with medical competence. For example, a miner's wife from Silesia, who as a socialist and advocate of reproductive rights was committed to helping her neighbours and friends, 


\section{Willem de Blécourt and Cornelie Usborne}

stood accused of no less than 150 abortions. But none of these had resulted in injury or death. She was on record as having operated in aseptic conditions and having had a genuine interest in anatomy, gynaecology and obstetrics, surrounding herself with medical textbooks and even keeping a foetus preserved in formalin. ${ }^{37}$ There were, of course, also many cases when women suffered injuries or even death (frequently the reason why the practices of lay abortionists came to the attention of the police in the first place and later to that of the researcher through criminal files). But these examples were often blown out of all proportion and used to justify the public vilification of so-called backstreet abortionists whose tarnished image was largely a medical construction. The worst cases of lay abortions were no worse than the worst cases of medical blunders and malpractice by well-established gynaecologists, of which there is evidence of many. The difference lay in public perception and judicial practice: lay operators always had a very bad press and were as a rule punished severely; in contrast, doctors were often given the benefit of the doubt in official reporting and could usually rely on the sympathy of medical expert witnesses. There were indeed many cases of women harmed by incompetent or unscrupulous doctors. The latter were prosecuted and tried but then often were let off scotfree. ${ }^{38}$

It is likely that wise women were also popular with aborting women for another reason: they had often developed their own methods and procedures which were different from those used by doctors and male lay operators. No lay abortionist seems ever to have used an anaesthetic, a commonplace practice with doctors but often feared by women for its risks and because they lost control of the proceedings at a time when they felt both vulnerable and mistrustful. Many wise women did not just insert a syringe but also tried to keep their clients relaxed and confident by massaging their stomach and by chatting to them about the operation. Furthermore, as we have seen, some of these abortionists kept an eye on their clients after the termination. ${ }^{39}$ Last but by no means least, as one of us has shown elsewhere, wise women proved to be more trustworthy than their male colleagues, both lay and medical. A fair number of male abortionists overstepped their remit and carried out additional operations without consent, or even assaulted women sexually when they were most at their mercy and defenceless. ${ }^{40}$

What this case study has revealed is that many women seeking an abortion avoided academic medicine for various practical and cultural reasons and sought alternative help. But it also points to the existence of a gendered perception of illness. We have seen above that the meaning attached to abortion by women was quite different to that held by male professionals who dominated the public discourse, such as doctors and lawyers. Both the latter described this as a criminal or immoral act (if they were conservative) or a necessary

\footnotetext{
37 Bundesarchiv Koblenz,

Reichsjustizministerium, 6233, Bd. 2, Bl. 87-97.

38 For example, $\mathrm{P}$ Hüssy, 'Begutachtung und gerichtliche Beurteilung von ärztlichen Kunstfehlern auf dem geburtshilflichen-gynäkologischen Gebiete', Beilageheft zur Zeitschrift für Geburtshilfe und Gynäkologie, Stuttgart, 1935, vol. 3; cf. LAB, Rep 58, 2138, the case of Dr med. Joachim of Berlin, who was defended by an eminent medical expert and acquitted on appeal after he had been convicted of 24 criminal abortions, one of which ended in death.
}

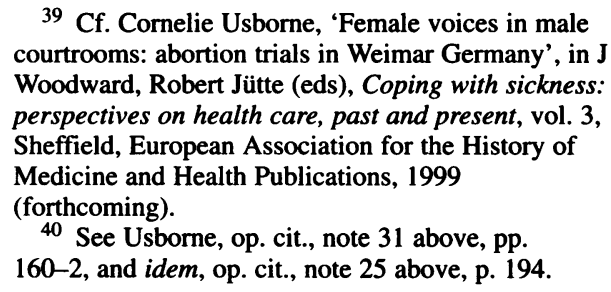

39 Cf. Cornelie Usborne, 'Female voices in male courtrooms: abortion trials in Weimar Germany', in J Woodward, Robert Jütte (eds), Coping with sickness: perspectives on health care, past and present, vol. 3, Sheffield, European Association for the History of Medicine and Health Publications, 1999 (forthcoming).

40 See Usborne, op. cit., note 31 above, pp. 160-2, and idem, op. cit., note 25 above, p. 194. 


\section{Women's Medicine, Women's Culture}

evil (if they were socialist/liberal abortion reformers) but most women, especially those from less privileged social backgrounds, thought of it as an acceptable way out of a personal or family dilemma, whether this was associated with physical or economic hardship or social stigma. Similar differences in the perception of pregnancy existed. In the official public discourse pregnancy, as long as it was not clearly life threatening, signified fulfilment of women's destiny. Yet, for women, an unwanted pregnancy was perceived as an illness and abortion its cure. Moreover, and this is the crux, for women "to have fallen" (pregnant) against their will was also perceived as a personal misfortune which destroyed their own or their family's equilibrium. As the case study from the Netherlands below illustrates in more detail, many women did not necessarily distinguish between a physical ailment and an emotional disaster, such as being abandoned by a lover, or having an alcoholic husband. Both were serious disturbances of their life and caused unhappiness. Thus, the same person was often consulted about how to deal with a variety of problems which we, steeped as we are in the rational discourse of science, rate as incongruous.

\section{Fortune-Telling}

With fortune-telling, as it was practised in the Netherlands during the late nineteenth and early twentieth centuries, ${ }^{41}$ there was never any argument about the availability of state registered practitioners, simply because fortune-telling was never officially taken seriously as a form of health care. Fortune-telling, though occasionally mentioned by campaigners against quackery, escaped the medical gaze, even if medicine and astrology had convergent histories. Only the clairvoyants among the fortune-tellers encountered medical disdain when prescribing remedies and thereby entering the medical domain properly. This was deemed an infringement of the Medical Act, ${ }^{42}$ irrespective of the purported benefits of the remedy advised; if necessary, physicians could always declare that such "quack" interventions deterred patients from seeking really effective cures.

Yet geographical availability was still one of the distinctive features of fortune-telling, if only because fortune-tellers were an almost exclusively urban phenomenon. In the cities they represented the independent type of woman entrepreneur who was not only tolerated but whose activity, notwithstanding its shadowy connotations, was very popular indeed, both with town dwellers as well as with people from the surrounding countryside. All main Dutch market towns could boast at least one fortune-teller, cities in the urban agglomeration of Holland had many more, and the trend was upward rather than downward. What, then, did they offer their prospective clients? In contrast to the medical profession, fortune-tellers operated above all within the female sphere. They were almost exclusively women and their clients were mainly women, too. The conservative estimate of the total number of fortune-tellers in the 1920s in the three main Dutch cities, Amsterdam, Rotterdam and The Hague, runs into at least 300 . This was a remarkable number, indeed, when compared with that of only 184 women doctors in the Netherlands as a whole in 1925. It certainly indicates that fortune-tellers served needs which university

41 See Willem de Blécourt, Het Amazonenleger. Irreguliere genezeressen in Nederland, $c a$. 1850-1930, Amsterdam University Press, 1999

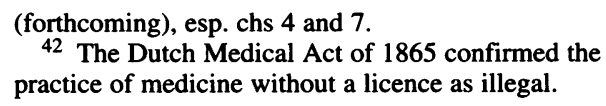

42 The Dutch Medical Act of 1865 confirmed the practice of medicine without a licence as illegal. 


\section{Willem de Blécourt and Cornelie Usborne}

trained doctors could not fulfil. The number, however, also implies that there was considerable competition among fortune-tellers, which necessitated specialisation.

Fortune-tellers were prosecuted only when they intruded into official medical areas and when they were suspected of inducing or aiding abortions, or of other immoral behaviour like prostitution or procuring. There are thus far fewer official texts available on the practices of fortune-tellers than there are on those of abortionists. To get a glimpse of what went on in the consulting room we have to rely on invariably hostile reports by contemporary investigative journalists or members of the vice-squad. The fortune-teller's own words, however, can often be heard beneath the criticism. They can also be made out in catchphrases in advertisements which primarily featured in the small ad section of local newspapers.

On the basis of their own representation, fortune-tellers can be divided into two main groups. The first consisted of "planetary experts" (a literal translation from the Dutch), ranging from the simple "planet readers" to the more distinguished "astrologists". The second group was made up of various types of clairvoyants, each with distinct practices, which nevertheless often overlapped: the "sleeping" or "spirit" mediums, the "somnambules", the "psychometrists", and the "clairvoyants" proper. Clairvoyants were subdivided into what in Dutch are called helderzienden, and "clairvoyants", a term derived from the French. The use of foreign words indicated a higher status or at least the aspirations to cater for the better type of client. The main difference between the two groups of fortune-tellers was their use of utensils. In theory clairvoyants had to make do with their five senses, possibly supplemented by a sixth one. The planetary experts, on the other hand, needed symbols.

Cards were, in fact, the fortune-tellers' most common tools. They may well have been used even by those who advertised with a more fancy label, such as "planetary expert", who would not necessarily have always charted horoscopes. A woman from Rotterdam who claimed that she had been born a "planetary expert" certainly did not. Nor did a certain Miss K. from The Hague who, despite calling herself a "planetary expert", advertised in 1895 that she "works with two decks of cards". Another "planetary expert" and "astrologist", also from The Hague, apparently worked with "seven decks of cards" and yet another could do it "with and without cards". ${ }^{43}$ Such advertisements were fairly typical during the first decades of the twentieth century. In a slight variant, Miss Louise, an Amsterdam "planet reader", who claimed that she had been born with the caul, used "foreign cards".44 Two Rotterdam journalists concluded in 1939: "A fortune-teller may call herself 'planetary expert', but of course she isn't". ${ }^{45}$ The language of fortune-telling was deceptive and advertisements applied their own rules rather than always faithfully representing daily speech. The common term for a fortune-teller was kaartlegster, literally a woman who lays cards. This term was used in newspaper-reports but also in the registers of residence and in court minutes, which shows that the women themselves referred to their trade in this way in every-day speech. Advertisements, however, were different. Since everyone knew that fortunes were told with the aid of cards, advertising

43 Haagsche Courant, 4 December 1895; 6 July 1914; 2 July 1923.

44 Maandblad tegen de kwakzalverij, September 1907, 27 (9).
45 Gerda Brautigam and Jan Liber, Het kwaad der waarzeggerij. Reportage van de zelfkant der samenleving, Rotterdam, Dagblad Voorwaarts, 1939, p. 45. 


\section{Women's Medicine, Women's Culture}

concentrated only on specific aspects of the trade. The rare explanation "without cards" appears to signify the same; by registering the exception, it indicated the norm. Even clairvoyants laid cards. For instance, Miss De Jong from The Hague advertised that she "brings clarity into every obscure affair and works with three decks of cards but also divines from portraits". 46 And the Amsterdam "spirit medium Dolores del Monte" claimed that she gazed at molten lead and ancient crystals but could also revert to her cards. ${ }^{47}$

Whereas card layers mostly helped with emotional and romantic problems, clairvoyants specialized in diagnosis and treatment of bodily misfortune. In the words of a journalist, "the questions posed to card layers and the like are mainly of an amorous nature, while those posed to somnambules are more related to cases of illness". 48 Somnambules, commonly called "sleeping women", possessed the uncanny capacity to "see" into their patient's body, the better so when they were touching some part of it. They could also "see" what remedies would ease or cure an ailment. In 1936, an Amsterdam somnambule, Mrs Schellevis, for example, described her approach to the court of law as follows: "During the treatment of the patient, I am in a light state of trance. I also prescribe the herbs when in trance. Afterwards the patients tell me what I have said and prescribed. I do not know myself what I have done". ${ }^{49}$ The last part of this statement referred to the prerogative of somnambulistic ritual. It had also been legally convenient, for it absolved somnambulists of responsibility. By the time Mrs Schellevis made her statement, however, this strategy had not carried any weight in court for over fifty years. The judges had changed their view and were now focusing on intent. There were also changes in the somnambules' practices. From about 1890 they had started to work independently, although they still occasionally used a (male) magnetist to induce their trance. This had been the norm during most of the nineteenth century, but in the first half of the twentieth century the help of the magnetists became less and less usual and most of the time somnambules operated on their own. This meant that their work overlapped increasingly with that of fortune-tellers in the way they advertised and in the way they engaged in clairvoyancy.

As was the case with female abortionists, with whom, at least in the Netherlands, fortune-tellers shared the same urban and social space, considerations of class and gender informed the communication between the provider of help and her client. Although women (and a few men) of all strands of society at one time or another used the fortuneteller's services, visits from upper-middle-class clients were reported in a tone of surprise and disapproval. This disdain not only reveals the bourgeois norms of the time, it also indicates class-specific popularity. It was indeed the case that women from the lower strata of early twentieth-century society provided fortune-tellers with their main source of income. Fortune-tellers, who were in their turn recruited from the working, artisan and trading classes themselves, thus conveyed to their clients a sense of the familiar as to a shared social background. But the rules of the game also demanded a certain exotic quality to do with the mystery of the cards, though only minimally with apparel or the use of a pseudonym, and a domineering act. This fine balance between the overpowering strange

46 Haagsche Courant, 9 August 1915.

47 Municipal Archive of Amsterdam, library nrs. $\mathrm{U} 00510$ and $\mathrm{U} 00507$.

48 Quoted in the Maandblad tegen de kwakzalverij, March 1918, 38 (3).

49 Maandblad tegen de kwakzalverij, July 1936, 56 (7). 


\section{Willem de Blécourt and Cornelie Usborne}

and the familiar social intercourse returned in the fortune-teller's play of words. She knew everything, yet the client was always right, a paradox which only bothered rationalists.

From our point of view today clairvoyants' diagnoses seemed vague and therefore unsatisfactory. Typically, they would refer to a general weariness or weakness, to "nerves", "alternating fevers", and "dirty glandular matter". But for many women at the time this added to the appeal of these healers. Such undefined, lingering illnesses were problems academic doctors were in no position to treat satisfactorily. Fortune-tellers were attractive precisely because their diagnoses left plenty of room for patients to insert their particular complaints and perceptions. The Amsterdam somnambule mentioned above went as far as encouraging her patients to spell out to her what ailed them when she was, of course, supposed to "see" it herself. This balance between the authority of the clairvoyant (it was hard to contradict someone who was supposedly in trance) and the space provided for patients to relate their own stories, was probably the decisive factor in the popularity of the clairvoyants.

Card layers, in their turn, had to rely on the external authority of the cards and on their own powers of interpretation. The figures of speech they used to link the general symbolism of the cards to the particular problems of the client can be identified as corrective clarification and post facto interpretation, i.e. they tried somehow to tease out their client's particular problem and then readjusted their explanations accordingly.

Why did women consult fortune-tellers? The indications are that marital and domestic problems were the principal reasons. Mrs “Adrino", a fortune-teller in The Hague, confided to one of her visitors: "Women come to me with all kinds of problems. One doesn't trust her husband, another wants to have a boyfriend, a third one is forced to marry". ${ }^{50}$ Fortune-tellers were usually consulted by women who had problems related to their present or future household. If single they wanted to know and be reassured about their lovers, about their future husband, when they would marry, whether their marriage would be a good one and how many children they would bear. Married women typically wanted to know whether their husband was faithful, or they sought advice on weaning him off drink, how to lose weight, how to become pregnant or, conversely, how to rid themselves of an unwanted pregnancy. Moreover, women approached fortune-tellers to help confirm or dispel a suspicion of a misdemeanour committed by a member of the family or household on occasions when the suspects could not be approached directly. Fortune-tellers also ventured to ease tensions that people were unable to ease themselves. The fortune that was told by Dutch fortune-tellers was the one of homely happiness, of the ideal, normative Dutch marriage in which the husband provided for his wife and children. It both reinforced and adapted bourgeois norms.

\section{Female Cultures of Healing}

These examples may surprise in their unusual definition of ill health and healing. Yet, they only reflect many, possibly most, women's perception in European society of the last 150 years. They illuminate typical emotional and physical problems of women whose lives were intimately associated with the household and with reproduction. The fact that

50 Municipal archive Den Haag, police archives, inv.nr. 2559, nr. 47. 
resorting to fortune-telling in cases of misfortune or unhappiness seems so strange to us has much to do with an unwitting internalization of a male model of illness which emerged in the late nineteenth century. Since the advent of health insurance ${ }^{51}$ it increasingly fell to doctors to adjudicate on their patients' state of health. Illness was usually pronounced when patients were considered to be incapable of working. Conversely a patient's ability to work was a sign of good health. But this approach depended on a patriarchal concept of work, i.e. waged labour outside the home which ignored women's unpaid, and frequently even paid, domestic work. ${ }^{52}$ Consequently, this work-related definition of illness often had little relevance to women's lives. In order to appreciate women's own understanding of illness we need to see it from a woman's point of view; this might well entail a reconsideration of received ideas about illness and health and what constituted an appropriate therapy, too.

In our examples we found that within the female culture of health and healing women did not necessarily respect the dialectical construction made by academic medicine of the physical versus the psychological nor did they concur with the distinction between the effect a problem had on the individual and that which it had on the immediate family or the wider household. In the dominant medical model, constructed by male scientists and influenced by notions of masculinity, illness was associated with the public sphere. Here the symptoms were generally physiological and the treatment was accordingly physical: either the administration of drugs or more invasive methods like surgery. In contrast, women's experiences of illness and recovery were shaped by a female culture of women's networks and their inextricable link with domestic affairs. Illness was not necessarily confined to physiological suffering but was perceived as a wider problem which was enmeshed with the well-being of the family. Its character was often defined as much by its impact on other members of the household as on the self. That is why an unwanted pregnancy, an alcoholic husband or an unfaithful lover were not necessarily perceived as different categories of problems but as misfortunes that had to be overcome by whatever means easily available on an open medical market. It was not that working-class women did not avail themselves of doctors' services, they may indeed have consulted them in certain circumstances, particularly if they were insured. But they did not do so to the exclusion of lay healers, especially if these were within easy reach as part of a neighbourhood network of information, ${ }^{53}$ and approachable because they shared the same cultural values.

\footnotetext{
51 Insurance in Germany was introduced on an ad hoc basis in the early 1840 s and on a national scale in the early 1880 s; cf. Reinhard Spree,

'Kurpfuscherei-Bekämpfung und ihre soziale Funktionen', in Alfons Labisch and Reinhard Spree (eds), Medizinische Deutungsmacht im sozialen Wandel des 19. und 20. Jahrhunderts, Bonn, Psychiatrie-Verlag, 1989, pp. 103-22, 112, and Ute Frevert, 'Professional medicine and the working classes in imperial Germany', J. contemp. Hist., 1985, 20: 637-58. About attempts to have nonuniversity trained healers working for insurance companies, see Marina Lienert, "“Naturheilkunde ist keine Wissenschaft!" Naturheilvereine, Ortskrankenkassen und Parteien in den
}

Auseinandersetzungen um die Errichtung eines Lehrstuhls für Naturheilkunde an der Universität Leipzig (1894-1924)', in Dinges (ed.), op. cit., note 15 above, pp. 59-78. In the Netherlands national health insurance was introduced only during the German occupation in 1941 but there were local and confessional insurance schemes in operation before.

52 Cf. Barbara Harrison, Not only the 'dangerous trades': women's work and health in Britain, 1880-1914, London, Taylor \& Francis, 1996.

53 The concept of "lay referral system" would be appropriate here, if it had been without connotations with patriarchal medical organisations, cf. Graham, op. cit., note 10 above, pp. 31-2. 


\section{Willem de Blécourt and Cornelie Usborne}

The two case studies about abortion and fortune-telling derive from German and Dutch sources respectively. They could well have been taken from other countries since both practices were prevalent all over Europe, yet in different contexts their form and content would have differed, too. Historians, after all, seek to discover the specificity of phenomena at particular times and places as well as the change over time. This article, therefore, seeks to inspire research into similar areas of the female culture of healing which combined both orthodox and heterodox practices in a manner which suited the particular circumstances and needs at the time.

In this paper we have discussed two aspects of women's medicine that are usually absent from mainstream medical history. How does this tie in with the theme "alternative medicine"? Does the fact that women constituted the largest group of users of "alternative medicine" 54 indicate that there was indeed a large overlap between the clientele of fortune-tellers and that of abortionists and "alternative" healers? However "alternative medicine" is defined, it is still categorized and defined by official medicine, internally divided though the latter may be. This has indeed been pointed out on several occasions. ${ }^{55}$ As long as illness is defined according to the dominant biomedical canon, the incommensurability between the biomedical approach and the cultural, constructivist approach to medical history is denied. ${ }^{56}$ Every advance on different cultures of healing that is thought of in terms of biomedical historiography is doomed to fall into the same trap: if cultures of healing are negatively defined as not official (or whatever synonym is applied), their structure, coherence and meaning still derive from their definer instead of from themselves.

Gender offers a means to escape this pitfall, as indeed class or race would do in the appropriate setting. A look at subordinate cultures of healing, in this case women's cultures of healing, enables us to cut through the alternative-official dichotomy and offer an alternative for "alternative".

\footnotetext{
54 For example, Ursula Sharma, Complementary medicine today: patients and practitioners, London and New York, Tavistock/Routledge, 1992, pp. 19-20.

55 For example, Matthew Ramsey in this issue.

56 Cf. Charles E Rosenberg, 'Introduction.
}

\author{
Framing disease: illness, society, and history', in \\ Charles E Rosenberg and Janet Golden (eds), \\ Framing disease: studies in cultural history, New \\ Brunswick, Rutgers University Press, 1992, \\ pp. xiii-xxvi.
}

